\begin{tabular}{|l|l|}
\hline $\begin{array}{l}\text { 2. To: (Receiving organization) } \\
\text { Technical Operations }\end{array}$ & $\begin{array}{l}\text { 3. From: (Originating Organization) } \\
\text { Process Engineering }\end{array}$ \\
\hline 5. Proj./Prog./Dept./Div.: & $\begin{array}{l}\text { 6. Design Authority/ Design Agent/Cog } \\
\text { Engr.: }\end{array}$ \\
Spent Nuclear Fuel Project & T.B. Bergman \\
\hline
\end{tabular}

8. Originator Remarks:

For release

11. Receiver Remarks: 11A. Design Baseline Document? [] Yes [X] No
4. Related EDT No.:

$\mathrm{N} / \mathrm{A}$

7. Purchase Order No.:

N/A

9. Equip./Component No.:

$N / A$

10. System/Bldg./facility:

$\mathrm{MCO}$

12. Major Assm. DWg. No.:

N/A

13. Permit/Permit Application No.: $N / A$

14. Required Response Date:

$\mathrm{N} / \mathrm{A}$

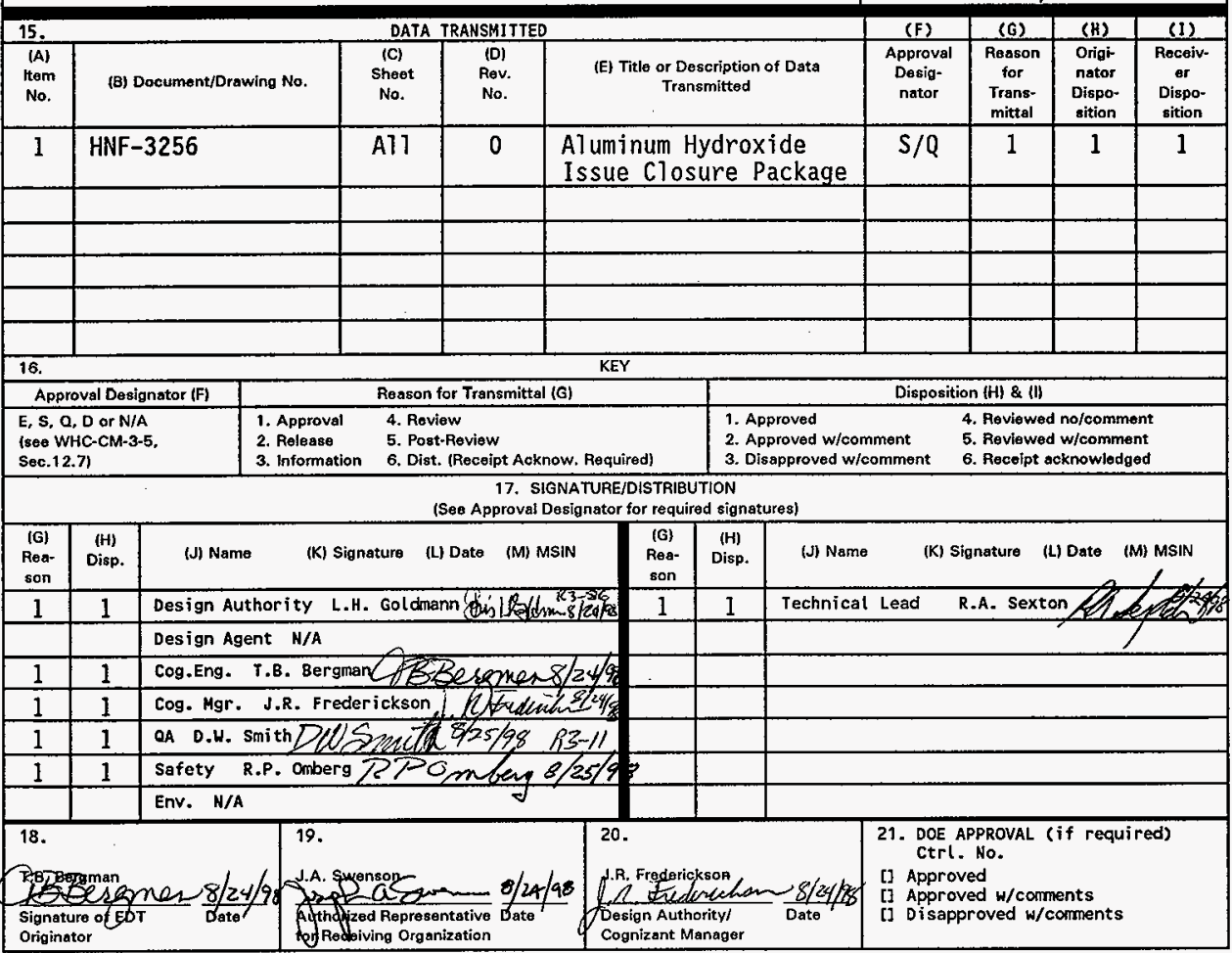

BD-7400-172-2 (05/96) GEF097 


\title{
ALUMINUM HYDROXIDE ISSUE CLOSURE PACKAGE
}

\author{
R. A. Sexton* and T. B. Bergman
}

DE\&S Hanford, Inc., Richland, WA 99352

U.S. Department of Energy Contract DE-AC06-96RL13200

$\begin{array}{lll}\text { EDT/ECN: } 625080 & \text { UC: } 510 \\ \text { Org Code: } & 2 T 910 & \text { Charge Code: LBOX8 } \\ \text { B\&R Code: } & \text { EW7040000 } & \text { Total Pages: } / /\end{array}$

Key Words: Aluminum Hydroxide, Spent Nuclear Fue1, Technical Issue cTosure

Abstract: Aluminum hydroxide coatings on fuel elements stored in aluminum canisters in $\mathrm{K}$ West Basin were measured in Ju7y and August 1998. Good quality data was produced that enabled statistical analysis. to determine a bounding value for aluminum hydroxide at a $99 \%$ confidence level. The updated bounding value is $10.6 \mathrm{~kg}$ per Multi-Canister overpack (MCO), compared to the previously estimated bounding value of 8 $\mathrm{kg} / \mathrm{MCO}$. Thermal analysis using the updated bounding value, shows that the MCO generates oxygen concentrations that are below the lower flammability limits during the 40-year interim storage period and are, therefore, acceptable.

*Technical Resources International, Inc., Richland, Washington

TRADEMARK DISCLAIMER. Reference herein to any specific comercial product, process, or service by trade name, trademark, manufacturer, or otherwise, does not necessarily constitute or imply its endorsement, recommendation, or favoring by the United states Government or any agency thereof or its contractors or subcontractors.

Printed in the United States of America. To obtain copies of this document, contact: Document control Services, P.O. Box 950, Mailstop H6-08, Richland WA 99352, Phone (509) 372-2420; Fax (509) 376-4989.
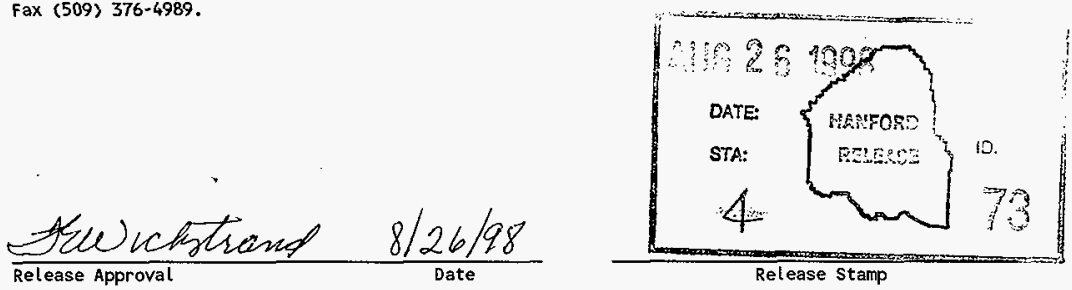

\section{Approved for Public Release}


HNF-3256, Rev. 0

\section{TABLE OF CONTENTS}

1.0 SUMMARY . $\quad . \quad$. $\quad . \quad$. $\quad . \quad . \quad . \quad$. 3

2.0 STATEMENT OF ISSUE $\quad . \quad . \quad . \quad . \quad . \quad . \quad . \quad . \quad$. 3

3.0 BASIS OF CLOSURE $\quad$. . . . . . . . . . . . 3

4.0 DISCUSSION $\quad . \quad$. $\quad . \quad . \quad . \quad . \quad . \quad 5$

5.0 REFERENCES . . . . . . . . . . . . . 10 
HNF-3256, Rev. 0

Issue Closure Package

Issue: $\quad$ Aluminum Hydroxide

Lead:

R. A. Sexton

Technical Resources

International

Approvals:

Chief Engineer:

A. M. Segrest

DE\&S Hanford

Technical Operations:

J. A. Swanson

Manager

DE\&S Hanford

Process Engineering:

J. R. Frederickson

Manager

DE\&S Hanford

Nuclear Safety:

Robert G. Morgan

Manager

DE\&S Hanford

MCO Design Authority:

L. H. Goldman

DE\&S Hanford

Operations:

C. A. Thompson

- DE\&S Hanford

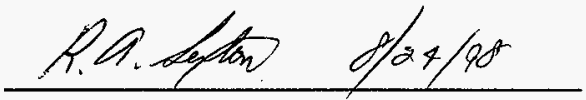

Signature
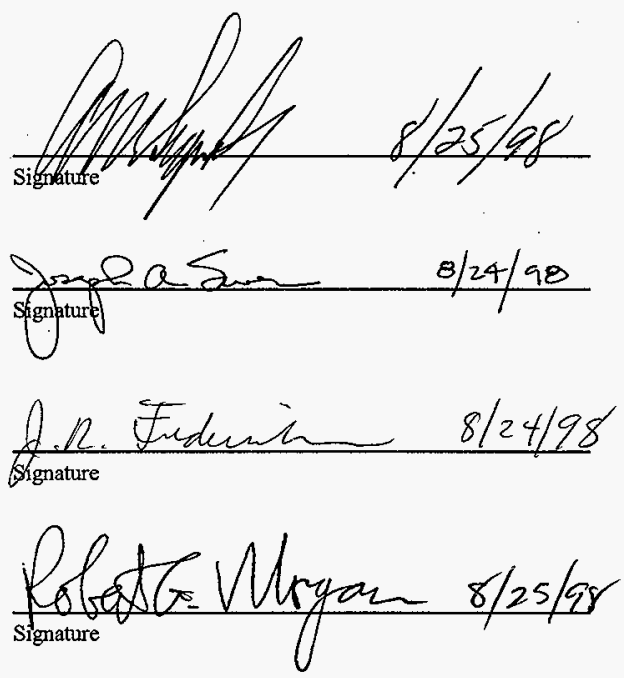

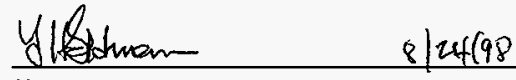

Signature

CA the 8/25/98

Signature

2 
HNF-3256, Rev. 0

\subsection{Summary}

Aluminum hydroxide coatings on fuel elements stored in aluminum canisters in $\mathrm{K}$ West Basin were measured in July and August 1998. Good quality data was produced that enabled statistical analysis to determine a bounding value for aluminum hydroxide at a $99 \%$ confidence level. The updated bounding value is $10.6 \mathrm{~kg}$ per Multi-Canister Overpack (MCO), compared to the previously estimated bounding value of $8 \mathrm{~kg} / \mathrm{MCO}$. Using the updated bounding value, thermal analysis shows that the fuel in the MCO generates oxygen concentrations during the 40-year interim storage period below the lower flammability limit, which is acceptable.

\subsection{Statement of the Issue}

A coating of aluminum hydroxide has been found on some fuel stored in aluminum canisters in the K-West Basin. Aluminum hydroxide represents a source of bound water in MCOs that contributes to oxygen production during storage. During interim storage, oxygen can be generated by radiolysis of aluminum hydroxide and can be consumed by reaction with exposed fuel and scrap surface area. Analysis of potential oxygen concentrations in the MCO was done through thermal modeling (Duncan and Plys 1998 and Packer 1998a) and had been based on an estimated bounding value of $8 \mathrm{~kg}$ of aluminum hydroxide in a single MCO (Sloughter 1997). Additional measurement data is needed, however, to establish a bounding value to the degree of confidence necessary to support the safety basis for CVD processing and interim storage of the MCO.

\subsection{Basis of Closure}

Resolution of the issue depends on the ability to show that the amount of aluminum hydroxide present in a bounding MCO is low enough that oxygen concentration remains below the $4 \%$ lower flammability limit throughout the 40 -year interim storage period.

An updated bounding value for aluminum hydroxide content was generated as a result of in-basin examination of fuel elements in aluminum canisters in K West Basin (Pitner 1998.) Multiple measurements of aluminum hydroxide coating thicknesses were combined with realistically conservative assumptions about fuel surface area in the $\mathrm{MCO}$ to calculate an updated bounding value of aluminum hydroxide of $10.6 \mathrm{~kg} / \mathrm{MCO}$ at a $99 \%$ confidence interval (Jensen and Wilmarth 1998.) This exceeds the original estimated value of $8 \mathrm{~kg} / \mathrm{MCO}$ that had been used in previous calculations. This bounding value applies to an $\mathrm{MCO}$ containing five baskets of Mark IV fuel. An MCO containing a scrap basket or an MCO containing Mark IA fuel will have a lower quantity of aluminum hydroxide.

Thermal analysis of MCOs with the updated aluminum hydroxide value (Packer 1998b) were 
performed with the same model that had previously been used in calculations to determine gas composition and internal MCO pressure during interim storage with the lower bounding value. As in previous calculations, MCOs containing Mark IA fuel were considered bounded by those containing Mark IV fuel. (Duncan and Plys 1998, and Packer 1998a.) Packer 1998b was reviewed for application of the model. Earlier calculations using this model were subjected to an external peer review (Duncan 1998a) in accordance with Office of Civilian Radioactive Waste Management procedures.

Duncan and Plys 1998 concluded that a lower flammability limit of $4 \%$ for oxygen is a conservative recommendation for a $\mathrm{He}_{\mathrm{H}} \mathrm{H}_{2}-\mathrm{O}_{2}$ system. That analysis also demonstrated a relationship between reactive fuel surface area and hydrated uranium oxide. Increased fuel surface area results in greater oxygen consumption rates than the increased oxygen production rates associated with radiolysis of the hydrate; therefore, MCOs of greatest concern are those with high quantities of aluminum hydroxide and low exposed uranium surface area.

Packer 1998b, using the updated bounding value for aluminum hydroxide, indicates that MCOs with extremely low reactive surface areas $\left(0.1 \mathrm{~m}^{2}\right.$ or less) and high power levels (400 Watts per $\mathrm{MCO}$ or greater) do have the potential for exceeding the $4 \%$ lower flammability limit over the 40 -year interim storage period. This analysis also demonstrates that reactive surface area of 0.25 $\mathrm{m}^{2}$ or greater provides sufficient gettering to assure that oxygen concentrations will not exceed the 4\% lower flammability limit. In Ball and Duncan 1998, a distribution of best estimate scrap reactive surface area, using a Monte Carlo method, demonstrated that any MCO with a scrap basket will have at least $1 \mathrm{~m}^{2}$ of reactive surface area. Therefore, the presence of a scrap basket in an MCO containing the bounding value of aluminum hydroxide and high power levels is sufficient to assure that the oxygen concentration will remain below $4 \%$ throughout the interim storage period.

MCOs loaded with at least one scrap basket will require no special actions for normal operations. For those MCOs that have very low reactive surface areas, i.e., no scrap basket, it will be necessary to either:

- demonstrate that no more than $75 \%$ of the loaded fuel was taken from aluminum canisters to assure that the aluminum hydroxide content remains below $8 \mathrm{~kg} / \mathrm{MCO}$ (the original bounding value that was determined to be acceptable in all cases); or

- increase the initial overpressure from $1.5 \mathrm{~atm}$ to $2.5 \mathrm{~atm}$ to dilute the oxygen generated during the interim storage period.

Packer $1998 \mathrm{~b}$ evaluated the impact of increasing the initial overpressure in the $\mathrm{MCO}$ from the current $1.5 \mathrm{~atm}$ helium to $2.5 \mathrm{~atm}$. This analysis demonstrated that with a $2.5 \mathrm{~atm}$ initial overpressure, an MCO containing the bounding value of aluminum hydroxide at high power levels remained below the $4 \%$ lower flammability limit throughout the interim storage period, 
HNF-3256, Rev. 0

even with no reactive surface area.

Based on the updated data and thermal analysis, MCOs will fall into the categories identified in the following table.

MCO Characteristics Based on Updated Aluminum

Hydroxide Measurements and Thermal Analysis

\begin{tabular}{|c|c|c|c|c|c|}
\hline Characteristic & $\begin{array}{c}\text { Current } \\
\text { data }\end{array}$ & \multicolumn{4}{|c|}{ Updated data } \\
\hline Futel baskets (Mark IV) & 4 & 4 & 3 & (5. & 5. \\
\hline Scrap Baskets. & .11 & 1. & 2.2 & 0 & 0.9 \\
\hline $\begin{array}{l}\text { Equivalent fuel } \\
\text { elements }\end{array}$ & 255 & 255 & 240 & 270 & 270 \\
\hline Minimum surface area ${ }^{1}$ & $1.0 \mathrm{~m}^{2}$ & $1.0 \mathrm{~m}^{2}$ & $2.0 \mathrm{~m}^{2}$ & TBD & TBD \\
\hline $\begin{array}{l}\% \text { fuel from } \mathrm{KW} \\
\text { aluminum canisters }\end{array}$ & $0-100 \%$ & $0-100 \%$ & $0-100 \%$ & $0-75 \%$ & $76-100 \%$ \\
\hline $\begin{array}{l}\text { Bounding value of } \\
\text { aluminum hydroxide }\end{array}$ & $\leq 8 \mathrm{~kg}$ & $\leq 10.1 \mathrm{~kg}$ & $\leq 9.7 \mathrm{~kg}$ & $\leq 8 \mathrm{~kg}$ & $\leq 10.6 \mathrm{~kg}$ \\
\hline Helium overpressure ${ }^{3}$ & $1.5 \mathrm{~atm}$ & $1.5 \mathrm{~atm}$ & $1.5 \mathrm{~atm}$ & $1.5 \mathrm{~atm}$ & $2.5 \mathrm{~atm}$ \\
\hline
\end{tabular}

\footnotetext{
1 Ball and Duncan 1998

2 Jensen and Wilmarth 1998

${ }^{3}$ Packer 1998b
}

The revised aluminum hydroxide bounding value of $10.6 \mathrm{~kg} / \mathrm{MCO}$ will be incorporated into the SNF Project Technical Databook for use in process design and safety basis calculations.

\section{4,0 Discussion}

Key considerations for determining if the bounding $\mathrm{MCO}$ will remain below the lower flammability limit for oxygen concentration throughout the interim storage period are:

- the volume of aluminum hydroxide present in the MCO which strongly influences the amount of water available for radiolysis,

- the amount of exposed uranium metal present in the $\mathrm{MCO}$ which determines the reactive surface area available to capture oxygen being released during radiolysis, and

- the power level of the MCO which drives the rate of radiolysis which occurs throughout 
HNF-3256, Rev. 0

the interim storage period.

\section{Aluminum Hydroxide Content}

The total number of aluminum canisters in the K-West Basin is approximately 780 , which represents $20 \%$ of the total of 3842 in that basin. Some groupings of aluminum canisters in the $\mathrm{K}$-West basin are large enough that a bounding estimate of aluminum hydroxide must be based on the assumption that all of the fuel in an MCO could come from aluminum canisters. Aluminum hydroxide coatings have only been observed on fuel elements in the closed canisters of $\mathrm{K}$ West Basin and not in the open canisters of $\mathrm{K}$ East Basin. As a result, no actions related to aluminum hydroxide content are required for MCOs loaded with fuel elements stored in K East Basin.

An intensive campaign was conducted in $\mathrm{K}$ West Basin to obtain measurements of aluminum hydroxide coating thicknesses on fuel elements stored in aluminum canisters. Specially developed eddy current probes were used to measure the outer and inner fuel elements with an accuracy of one-half of one-thousandth of an inch. The probes were attached to 25 foot long poles for the underwater measurement of the coating thicknesses. Once a candidate canister was retrieved from the basin, it was transferred to the dummy elevator pit. The lid of the canister barrel was removed and individual fuel elements were extracted and measured for coating thickness. Both inner and outer fuel elements were examined, with most emphasis on the outer elements. Typically two fuel elements from opposite sides of the canister barrel were extracted and examined. Coating thickness measurements were generally performed at two or three elevation levels on two opposing sides of the fuel element. Nineteen canisters were opened and examined and 214 measurements of coating thickness on 37 outer fuel elements and 8 inner fuel elements were obtained. Measured coating thicknesses ranged from 0 to 6 mils.

Checkout and acceptance testing of the eddy current measurement system were conducted in the Cold Test Facility in the 305 Building. Data quality was assured by frequent calibration checks performed on the measurement probes. Calibration standards consisting of various thickness shims affixed to zircaloy cylinders were fabricated to test out the eddy current probes. Zircaloy is the cladding material on $\mathrm{N}$ Reactor fuel elements, and the plastic shims simulated the non-electrically conducting aluminum hydroxide coating on the fuel. Separate laboratory measurements on plastic shims and aluminum hydroxide confirmed the ability of these shims to accurately represent aluminum hydroxide coatings. Calibration of the eddy current probes were performed at the beginning of each workday to generate current calibration curves. The calibration of each probe being used was checked at intervals no longer than four hours apart. A final calibration check was also made at the end of the workday. Additionally, calibrations were performed each time an eddy current probe (outer or inner element) was changed out. All eddy current measurement operations were conducted under the cognizance of a certified technician. The measurement process is summarized in 
Pitner 1998.

A statistical evaluation of the data (Jensen and Wilmarth 1998) was performed to calculate means and confidence intervals on the mass of aluminum hydroxide in an MCO. The conversion from coating thickness measured during in-basin testing to the mass of aluminum hydroxide in an $\mathrm{MCO}$ is based on the theoretical density of aluminum hydroxide and the surface area of the outer and inner fuel elements. The statistical evaluation assumed that the fuel assemblies in the MCO come only from aluminum canisters and that the fuel canisters selected to make up an MCO are a random sample from the population of aluminum canisters. The means and upper limit to one-sided $99 \%$ (UL( $99 \%)$ ) confidence intervals on the mass of $\mathrm{Al}(\mathrm{OH})_{3}$ in an $\mathrm{MCO}$ are given in the following table:

Mass of Aluminum Hydroxide in an MCO (in kg)

\begin{tabular}{|l|c|c|}
\hline Case & Mean & UL(99\%) \\
\hline Case 1 (5 fuel baskets) & 5.75 & 10.61 \\
\hline $\begin{array}{l}\text { Case 2 (4 fuel baskets/1 scrap } \\
\text { basket) }\end{array}$ & 5.43 & 10.12 \\
\hline $\begin{array}{l}\text { Case 3 (3 fuel baskets/2 scrap } \\
\text { baskets) }\end{array}$ & 5.11 & 9.65 \\
\hline
\end{tabular}

As a result, $10.6 \mathrm{~kg} / \mathrm{MCO}$ is a conservative bounding value to be used for process design and safety basis calculations. No additional work is necessary to further refine the bounding value for aluminum hydroxide content of an $\mathrm{MCO}$.

\section{Reactive Surface Area}

For an MCO with all fuel baskets, Ball and Duncan, 1998, identifies the minimum reactive surface area for K-West basin MCOs as $0.08 \mathrm{~m}^{2}$. Packer $1998 \mathrm{~b}$ demonstrates that a minimum reactive surface area in this range is not quite enough to assure oxygen concentrations below the lower flammability limit with bounding aluminum hydroxide without the use of mitigating operational measures.

The addition of a scrap basket to the MCO increases the surface area of exposed uranium metal to at least $1 \mathrm{~m}^{2}$ which is well above the minimum surface area necessary to assure the $\mathrm{MCO}$ remains below the lower flammability limit with no additional mitigating actions. Additional work to establish a minimum reactive surface area for an $\mathrm{MCO}$ with no scrap baskets could be used to refine the mitigating operational measures recommended. For example, if a minimum surface area of $0.05 \mathrm{~m}^{2}$ in an MCO containing all fuel baskets can be defended, the additional overpressure could be reduced from $2.5 \mathrm{~atm}$ to $2.0 \mathrm{~atm}$ or the percentage of aluminum fuel 
allowable in an MCO before a scrap basket would be needed could be increased. Refinement of the minimum surface area may present an opportunity for process optimization at a later date, but the overall effect is expected to be small and will not change the nature of the operational measures recommended.

If helium overpressure in the range of $2.5 \mathrm{~atm}$ were selected, it is within the current operational capability. Overpressure could easily be applied to all $\mathrm{MCOs}$, or it could be applied selectively to those known to be high in fuel from aluminum canisters. Since the number of MCOs that would exceed a high percentage of fuel from aluminum canisters and that would not have a scrap basket is expected to be low, the operational impacts of meeting this requirement are expected to be minimal.

\section{Power Level}

In an MCO with some reactive fuel surface area, increased thermal power also increases the fuel oxidation reaction rate which lowers the oxygen concentration in the gas phase. However, if no reactive surface area is assumed, an increase in thermal power only increases the radiolysis rate, thereby increasing the amount of oxygen present as a gas. The bounding thermal power shown in Duncan 1998b, is 776 Watts per MCO. However, the fuel stored in aluminum canisters is limited and none has high thermal power. The maximum decay heat of Mark IV fuel contained in aluminum canisters is 71.47 Watts per metric tonne of uranium. This yields a thermal power for a Mark IV MCO with all fuel elements from aluminum canisters of $453 \mathrm{~W}$. Some additional work is underway to examine the power level of fuel in aluminum canisters that may result in a reduction of the maximum power level attained by an $\mathrm{MCO}$ with $100 \%$ of its fuel from aluminum canisters. This could potentially reduce the oxygen concentration in the MCO during the interim storage period. This may present an opportunity for process optimization at a later date, but the overall effect is expected to be small and will not change operational measures recommended.

\section{Conservative Assumptions Used in Calculations}

There are a number of key parameters which impact the calculation of oxygen concentrations during interim storage. Because of uncertainty associated with many of these parameters, conservative values have been chosen for safety basis calculations. Key conservatisms identified in these calculations include:

- The updated bounding value is calculated assuming a $99 \%$ confidence interval and an MCO fully loaded with fuel from aluminum canisters. The actual average mass of aluminum hydroxide will be less than the bounding value and few, if any, MCOs will contain only fuel from aluminum canisters.

- Calculations in Packer 1998b assume the MCO is filled with fuel at the highest power level possible for fuel stored in aluminum canisters. Actual power level will be lower than the calculated maximum 453 Watts per $\mathrm{MCO}$, reducing the rate of radiolysis and, 
therefore, the amount of oxygen generated.

- The conversion from coating thickness per element to aluminum hydroxide mass assumed that the aluminum hydroxide was at $100 \%$ of the theoretical density. Actual density of the coating is probably between 80 and $90 \%$ of theoretical density.

- Fuel assemblies are of different lengths depending on their position in the reactor and the type of fuel (Mark IA or Mark IV). The conversion factor from coating thickness per element to aluminum hydroxide mass per fuel assembly assumed Mark IV fuel assemblies of the longest length fuel known to exist in the basins. Since only $78 \%$ of Mark IV fuel assemblies the longest length, the total surface area of the fuel in an MCO, and therefore, the mass of aluminum hydroxide, will normally be lower.

- The process of retrieving and cleaning the fuel assemblies prior to placement in the MCO will remove some of the aluminum hydroxide coating from the surface of the fuel element. The calculations take no credit for the removal of aluminum hydroxide coating that will occur during the fuel loading process.

With the exception of maximum MCO power levels, no further work is planned to modify the assumptions used in the calculations to reduce the amount of conservatism associated with the calculated bounding value of aluminum hydroxide in an MCO. Any data obtained as a result of future study that reduces these conservatisms may present an opportunity for process optimization at a later date, but do not affect the closure of the aluminum hydroxide issue. 
HNF-3256, Rev. 0

\subsection{References}

Ball, D. E., and D. R. Duncan, 1998, "Fuel Surface Area," HNF-SD-SNF-CN-017, Revision 3, DE\&S Hanford, Richland, Washington.

Duncan, D. R., 1998a, "OCRWM Peer Review Material for HNF-SD-SNF-TI-040, Rev. 1," EDT 624307, DE\&S Hanford, Richland, Washington.

Duncan, D. R., 1998b, "Spent Nuclear Fuel Project Technical Databook," HNF-SD-SNF-TI-015, Revision 3, DE\&S Hanford, Richland, Washington.

Duncan, D. R., and M. G. Plys, 1998, "MCO Internal Gas Composition and Pressure During Interim Storage," HNF-SD-SNF-TI-040, Revision 2, DE\&S Hanford, Richland, Washington.

Jensen, L. and S.R. Wilmarth 1998, "Summary Results From Statistical Analysis of Aluminum Trihydroxide Thickness Data," Letter Report 7A120-98-043, Lockheed Martin Hanford Company, Richland, Washington.

Packer, M. J., 1998a, "MCO Gas Composition for Low Reactive Surface Areas," HNF-3035, Revision 0, DE\&S Hanford, Richland, Washington.

Packer, M. J., 1998b, "MCO Gas Composition for Low Reactive Surface Areas," HNF-3035, Revision 0A, ECN \#645123, DE\&S Hanford, Richland, Washington.

Pitner, A. L. and S. L. Hecht 1998, "Highlight Report -- Aluminum Hydroxide Coating Thickness Measurements and Brushing Tests on K West Fuel Elements," Letter Report DESH9856982, DE\&S Hanford, Richland, Washington.

Sloughter, J. P., 1997, "Estimates of Particulate Mass in Multi-Canister Overpacks," HNF-1527, Revision 0, Numatec Hanford Corp., Richland, Washington. 


\section{DISTRIBUTION SHEET}

\begin{tabular}{|c|c|c|c|c|c|}
\hline \multirow{2}{*}{$\begin{array}{l}\text { To } \\
\text { Distribution }\end{array}$} & \multirow{2}{*}{\multicolumn{3}{|c|}{$\begin{array}{l}\text { From } \\
\text { SNF Process Engineering }\end{array}$}} & \multicolumn{2}{|l|}{ Page 1 of 1} \\
\hline & & & & \multicolumn{2}{|c|}{ Date August 25, 1998} \\
\hline \multicolumn{4}{|l|}{ Project Title/Work Order } & \multicolumn{2}{|c|}{ EDT No. 625080} \\
\hline \multicolumn{3}{|c|}{ Aluminum Hydroxide Issue Closure Package } & & \multicolumn{2}{|c|}{ ECN No. N/A } \\
\hline Name & MSIN & $\begin{array}{l}\text { Text } \\
\text { With All } \\
\text { Attach. }\end{array}$ & Text Only & $\begin{array}{l}\text { Attach./ } \\
\text { Appendix } \\
\text { Only }\end{array}$ & $\begin{array}{c}\text { EDT/ECN } \\
\text { Only }\end{array}$ \\
\hline
\end{tabular}

DE\&S Hanford, Inc:

T. B. Bergman (3)

D. W. Bergmann

R3-11

HO-40

D. R. Duncan

J. R. Frederickson

L. H. Goldmann

R3-86

R3-86

R3-86

R. G. Morgan

R. P. Omberg

R3-26

R3-26

A. M. Segrest

R3-11

J. A. Swenson

R3-11

C. A. Thompson

R3-86

SNF Project Files

R3-11

$x$
$x$
$X$
$x$
$x$
$X$
$X$
$x$
$x$
$x$
$x$

Fluor Daniel Hanford

N. H. Williams

R3-11 X

ARES Corporation

J. D. Cloud

R3-86 $X$

COGEMA Engineering

A. L. Pajunen

R3-86 X

Technical Resources International, Inc.

R. A. Sexton (3)

R3-86 X 